\title{
How Students' Perspectives about Online Learning Amid the COVID-19 Pandemic?
}

\author{
D S Bestiantono ${ }^{1}$, P Z R Agustina ${ }^{1}$, T-H Cheng ${ }^{2}$ \\ ${ }^{1}$ Department of Physics, Faculty of Mathematics and Natural Science, Universitas Negeri Surabaya, Surabaya 60231, \\ Indonesia \\ ${ }^{2}$ Graduate Institute of Science Education, National Dong Hwa University, Hualien 97401, Taiwan
}

\begin{tabular}{|c|c|}
\hline Article Info & ABSTRACT \\
\hline $\begin{array}{l}\text { Article history: } \\
\text { Received November 10, } 2020 \\
\text { Revised December 22, } 2020 \\
\text { Accepted December 23, } 2020 \\
\text { Available Online December 23, } \\
2020\end{array}$ & \multirow{2}{*}{$\begin{array}{l}\text { This exploration study inspects the perspectives of Indonesian junior } \\
\text { high school students towards learning courses amid Coronavirus } \\
\text { (COVID-19). Secondary students were overviewed to discover their } \\
\text { viewpoints about online training in Indonesia. The discoveries of the } \\
\text { investigation featured that web-based learning cannot create wanted } \\
\text { outcomes in immature nations like Indonesia, where a larger part of } \\
\text { understudies cannot get to the web because of specialized just as } \\
\text { money-related issues. The absence of eye-to-eye connection with the } \\
\text { educator, reaction time and nonattendance of conventional homeroom } \\
\text { socialization were among some different issues featured by advanced } \\
\text { education understudies. }\end{array}$} \\
\hline $\begin{array}{l}\text { Online Learning } \\
\text { COVID-19 } \\
\text { Indonesia } \\
\text { Internet Issues } \\
\text { Secondary Education } \\
\end{array}$ & \\
\hline (A) Check for updates open $\partial_{\text {Access }}$ cC & https://doi.org/10.46627/silet \\
\hline
\end{tabular}

\section{INTRODUCTION}

The World Health Organization (WHO) proclaimed COVID-19 as a worldwide general wellbeing crisis of global worry on 30th January 2020 just as a pandemic on eleventh March 2020 (Cucinotta \& Vanelli, 2020). The Health Ministry in Presidential Palace affirmed the initial two instances of COVID-19 in Indonesia on 2nd March 2020. As of 20 June 2020, the all-out quantities of instances of COVID-19 in the nation were 45,029 with 2,429 passing (Covid-19 Stats, 2020). In response to the COVID-19, Indonesian specialists shut all instructive foundations the nation over on March 2020. According to the requests given by the Indonesian Ministry of Education gave orders to advanced education establishments to begin planning for separation learning modes, reschedule the continuous tests and help their understudies online consistently until the COVID-19 emergency stays unaltered.

Since the beginning of Covid's entry into Indonesia to date, the impact on each sector has started to become serious, especially in the education sector. COVID-19 has had a severe impact on students, educators and educational associations around the world (Mailizar, Almanthari, Maulina \& Bruce, 2020). The pandemic has caused all education sectors ranging from schools, universities and colleges around the world to be forced to close their pages to reduce the level of social interaction (Toquero, 2020). By looking at some opinions which state that the risk of spreading Covid-19 from those who interact socially without maintaining a distance, almost everyone will feel uncomfortable. Nevertheless, because no one knows when this pandemic will completely disappear, educational organizations around the world are choosing to make effective use of specialized assets to create internet learning materials for students from every field of scholastics (Kaur, 2020). Many of the guidelines have been changed to adapt the conditions during a pandemic which makes everyone limited in activities outside the home (McPherson \& Bacow, 2015). 
Policy policies in the education sector began to emerge, ranging from learning guidelines to materials that had to be taught. Socialization and training, in this case, take an important role to be given overall by many companies, but there are still two obstacles in the education sector, namely First of all, from a large-scale perspective, almost nothing is regulated regarding the impact and adequacy of online training (McPherson \& Bacow, 2015). Second, the ability to educate effectively with care will likely vary depending on the broad range of learning goals that govern our instructional and instructive needs (Liguori and Winkler, 2020). Every school does not mean that all teachers understand technology; the age of the educators is also a consideration for the implementation of this virtual learning. Perhaps young educators can be more pro-active but not those who are over 45 years old.

Internet learning can be carried out in developing countries with caution (Basilaia \& Kvavadze, 2020) Indonesia must consider each region, however, in Indonesia there are still many areas that are far from the reach of the internet. Every individual does not necessarily have the tools for virtual learning. The absence of access to fast, moderate and reliable web associations hinders the internet adaptation cycle, especially for individuals living in provinces such as areas far from civilized capital cities (Wains \& Mahmood, 2008). Individual understanding in accessing the web is noteworthy, as we know that covid-19 arguably came without us having sufficient preparation to adapt quickly. Individuals who usually get training before starting something in this pandemic are required to start something along with learning to understand without being given training.

The abrupt change in internet learning is shifting to classic dexterity proportions $(\mathrm{Wu}, 2020)$, with some educational foundations that are essentially centered around the exchange of instructive substance to the world of computers and not explicitly on educational techniques and web-based delivery. Lack of proper communication with teachers is another important issue associated with internet learning. Also, concerning any substance of online courses are usually checked with influential course educators by email, which requires reaction time (Zhong, 2020). The virtual class cannot be considered essential for students who are students of material. Traditional homeroom teacher outreach is the main thing missing in internet learning. Comprehension only speaks to their peers carefully and never directly observes individual students, and in this way, the constant sharing of thoughts, information and data is mostly absent in the world of advanced learning (Britt, 2006).

Conditions like this make students' motivation in learning decrease because they are only faced with a screen containing writing every time (Toquero, 2020). Students do not have the freedom to explore the understanding of the material presented. This condition is a condition in which students must adapt quickly, more precisely in emergency learning (Pace, Pettit, \& Barker, 2020). The teacher must make the concept of learning as attractive as possible so that students do not feel bored; even learning cannot comply with standard teaching hours like normal conditions. This difficulty in online learning is a morning task of education leaders (for example, Ali \& Ahmad, 2011; Bukhsh, 2007; Farid et al., 2015; Yousuf, 2007), where e-learning is a strategy that is not needed to intensify learning and fostering cycles and smart innovation used by few public scientific foundations.

Some learning materials must be shortened in the explanation, and some materials take a long time to be understood by students. Ali and Ahmad (2011) argue that, just like traditional learning, there is good cooperation in separating schools between teachers and students, the substance is around being planned and forward-thinking, educators submitting, and being prepared with talents and having the necessary information. Nonetheless, the current situation is unique as well as the usual separation learning program, where all continuing education institutions are forced to carry out separation learning procedures regardless of constrained assets and assets.

Research led by Mailizar et al. (2020), recommends that student voices are essential in this issue, especially for students who are in areas far from the capital and not from wealthy families. The learning process must hamper what is even having to postpone school during the pandemic 
because of the missing online learning facilities. Making students understand the importance of learning and improving student learning motivation is very important in this pandemic period. Therefore, paying attention to the condition of students in learning must be done. Further examinations are expected to investigate the difficulties using e-discovering that prevent students from achieving their learning goals. Basilaia and Kvavadze (2020) also propose that the nature of online learning should be explored in consideration of students' understanding of learning.

\section{RESEARCH METHOD}

\section{Sample}

The critical reason for this exploratory study was to locate the overall mentalities of Indonesian secondary school students towards obligatory virtual learning process amid Coronavirus (COVID-19). The example of the examination included 180 secondary students: 90 male and 90 female members. The members included the first year 60 members, the second year 60 members, and the third year 60 members.

\section{Survey}

An online review method was utilized to assemble information about the perspectives of Indonesian secondary school students concerning internet instructing. The 10-item questionnaire was used to assess the effectiveness of online learning. A pilot test of the survey was administered to students of Budi Utomo Junior High School, Indonesia. Appropriate revisions were made based on their comments and suggestions. Necessary modifications were made based on their ideas and feedback.

\section{Data Analysis}

The data obtained through an online survey were analyzed by frequency of typical students' responses and were stated in percentages. Demographic data were obtained using the Likert scale and is reported in percentage of students' responses.

\section{RESULTS AND DISCUSSION}

First year students represented $33.3 \%(n=60)$ of study sample, whereas second year students represented $33.3 \%(n=60)$ of study sample, and third year students represented $33.3 \%(n=60)$ of study sample. Of the total 180 students, $33.3 \%(n=60)$ were between the age range of 13-14, whereas $33.3 \%(n=60)$ were between the age range of $14-15$, and $33.3 \%(n=60)$ were between the age range of $15-16.66 .6 \%(n=120)$ reported that they have proper access to the internet, $22.2 \%$ $(n=40)$ reported no proper access, while $11,1 \%(n=20)$ reported that they have limited access to the internet through a mobile phone or handheld device.

As shown in Table 1, 51.6\% students reported that signals availability/strength are the major problems behind limited internet access, $11.1 \%$ consider internet services too expensive for regular online connectivity, $34.9 \%$ reported other reasons for limited internet access. In examining whether students feel qualified to use a computer/laptop for online learning, $71.4 \%$ of students feel that they are well qualified to use computer/laptop for online learning. $61.1 \%$ of students reported that they are comfortable communicating digitally, while $11.1 \%$ feel that they are face problems in digital communication.

While responding to the question whether online and conventional learning is same, $67.5 \%$ reported that online learning is way different from conventional learning mode, while $18.3 \%$ feel that there is little difference between online and conventional learning. Only $10.3 \%$ of students feel that online learning is more motivating than conventional learning, while the majority of the students $(71.4 \%)$ feel voted against the notion that online learning is more motivating than conventional learning. When exploring the opinion of higher education students about the completion of entire university courses through the internet without difficulty, $50.8 \%$ students reported that it is not possible to complete entire university courses through online means effectively. In comparison, $18.3 \%$ reported that it is possible to complete an entire course through 
distance learning. $42.9 \%$ of students reported that they feel difficulties while doing group projects or assignments through distance education, while $34.1 \%$ of students feel that group projects and assignments can be completed digitally. While reporting about the effectiveness of face-to-face interaction, $78.6 \%$ of students feel that face-to-face contact with an instructor is necessary for learning and distance learning.

Table 1. Students Attitudes Regarding Online Learning

\begin{tabular}{|c|c|}
\hline Attitudes & No. $(\%)^{*}$ \\
\hline \multicolumn{2}{|c|}{ The main reason for limited Internet access } \\
\hline Cost/Too Expensive & $14(11.1)$ \\
\hline Signals availability/strength Problems & $65(51.6)$ \\
\hline Don't know how to use it & $3(2.4)$ \\
\hline Other & $44(34.9)$ \\
\hline \multicolumn{2}{|l|}{ I feel qualified to use a computer/laptop } \\
\hline Agree & $90(71.4)$ \\
\hline Somewhat Agree & $34(27)$ \\
\hline Disagree & $2(1.6)$ \\
\hline \multicolumn{2}{|c|}{ I am comfortable communicating electronically } \\
\hline Agree & $77(61.1)$ \\
\hline Somewhat Agree & $35(27.8)$ \\
\hline Disagree & $14(11.1)$ \\
\hline \multicolumn{2}{|c|}{ No difference between online and conventional learning } \\
\hline Agree & $17(13.5)$ \\
\hline Somewhat Agree & $24(19)$ \\
\hline Disagree & $85(67.5)$ \\
\hline \multicolumn{2}{|c|}{ Online learning is more motivating than conventional learning } \\
\hline Agree & $13(10.3)$ \\
\hline Somewhat Agree & $23(18.3)$ \\
\hline Disagree & $90(71.4)$ \\
\hline \multicolumn{2}{|c|}{ Complete university courses can be completed effectively through internet } \\
\hline Agree & $23(18.3)$ \\
\hline Somewhat Agree & $39(31)$ \\
\hline Disagree & $64(50.8)$ \\
\hline \multicolumn{2}{|c|}{ It is easy to complete group projects/assignments digitally } \\
\hline Agree & $43(34.1)$ \\
\hline Somewhat Agree & $29(23)$ \\
\hline Disagree & $54(42.9)$ \\
\hline \multicolumn{2}{|c|}{ Face-to-face contact with the instructor is necessary for learning } \\
\hline Agree & $99(78.6)$ \\
\hline Somewhat Agree & $16(12.7)$ \\
\hline Disagree & $11(8.7)$ \\
\hline
\end{tabular}

\section{Discussion}

Majority of the surveyed secondary education students have reservations about online/digital learning. Lack of access to internet facilities, lack of proper interaction and contact with students and instructors and ineffective technology were among the significant challenges faced by secondary education students of Indonesia. The sudden shift from traditional classrooms and face-to-face learning to online learning has resulted in a completely different learning experience 
for students. Most students do not have access to high speed or reliable internet services and are thus struggling with online learning.

Owing to the limited resources of educational institutions, only several institutions were able to introduce useful online classes during the initial months of COVID-19. The research also indicated additional challenges faced by students like lack of school socialization, group study issues and instructor's response time. Survey participants also reported that traditional classroom learning was more effective as compared to online learning or distance education. Thus, it can be concluded that online learning cannot produce effective results in developed countries like Indonesia, where a vast majority of students are unable to access the internet due to technical and monetary issues.

One of the less discussed areas of online education is the need of motivation for online learning. In traditional classes, students usually actively participate in academic activities due to their face-to-face engagement with instructor and class fellows. $71.4 \%$ of students reported that learning in the conventional classroom was more motivating than distance learning. As indicated by the majority of the students, they can manage their study time effectively online and can efficiently complete assignments in time, but complete courses cannot be completed online.

\section{CONCLUSION}

COVID-19 impacted the conventional learning method of academic institutions across the world. The administrations of schools, colleges and universities opted for online lectures/classes as an alternative way to resume education. Although online learning is proving helpful in safeguarding students' and faculty's health amid COVID-19 pandemic, however, it is not as effective as conventional learning. Online learning cannot produce desired results in developed countries like Indonesia, where a vast majority of students are unable to access the internet due to technical as well as monetary issues. This study addressed the effectiveness of online versus traditional classes, especially for students of higher education. As per this study, $73 \%$ of students had proper internet facility and $71.4 \%$ students felt that they were well qualified to use a computer/laptop for online classes even then $78.6 \%$ respondents felt that conventional classes were more effective as compared to online learning.

Apart from technical and monetary issues, students also reported a few other difficulties like lack of interaction with the instructor, response time and absence of traditional classroom socialization. The lack of on-school socialization has caused difficulties for students to do group projects in distance learning mode as reported by $42.9 \%$ of students. The result of this study also indicated that educational organizations need to improve their curriculum and design appropriate content for online lectures. Due to the difficulties mentioned above, $50.8 \%$ of students voted against the possibility of effectively completing entire courses through online learning. While comparing the effectiveness of conventional and online learning, $78.6 \%$ of students felt that face to face contact with their instructor was necessary for effective learning which is missing in distance learning mode. As per the instructions of $\mathrm{WHO}$, we now have to adjust our daily activities with COVID-19 for some time at least, which means that educational institutions have to design appropriate and useful content, arrange an effective delivery system and provide digital literacy training to their current faculty so better learning outcomes can be achieved.

\section{ACKNOWLEDGEMENTS}

Thanks to editorial and reviewer of SiLET journal who has provided many suggestions, motivations, assistance, and moral education during manuscript preparation. Special thanks are also dedicated to Junior High School students of Budi Utomo Jombang East Java Indonesia, especially students of class 7th grade, 8 th grade, and 9th grade, who have agreed to be a sample in this research. 


\section{REFERENCES}

Bandura, A. (1997). Self-efficacy: The exercise of control. Freeman.

Creswell, J. W. (2012). Educational research: Planning, conducting, and evaluating quantitative and qualitative research (4th Ed.). Pearson.

Lin, T-J, Liang, J.-C., \& Tsai, C.-C. (2015a). Identifying Taiwanese university students' physics learning profiles and their role in physics learning self-efficacy. Research in Science Education, 45(4), 605-624. https:// doi.org/10.1007/s11165-014-9440-z

Abbas, W., Ahmed, M., Khalid, R., \& Yasmeen, T. (2017). Analyzing the factors that can limit the acceptability to introduce new specializations in higher education institutions. International Journal of Educational Management.

Ahmad, I. (2020, April 5). Fata and the internet. The News. https://www.thenews.com.pk/print/639470-fata-and-the-internet

Ali, A., \& Ahmad, I. (2011). Key factors for determining students' satisfaction in distance learning courses: A study of Allama Iqbal Open University. Contemporary Educational Technology, 2(2).

Ali, N. U. (2020, April 2). Students disappointed with online teaching system amid COVID-19. Daily Times. $\quad$ https://dailytimes.com.pk/587446/students-disappointed-with-online-teachingsystem-amid-covid-19/

Basilaia, G., \& Kvavadze, D. (2020). Transition to online education in schools during a SARS-CoV2 coronavirus (Covid-19) pandemic in Georgia. Pedagogical Research, 5(4), 1-9.

Britt, R. (2006). Online education: A survey of faculty and students. Radiologic Technology, 77(3), 183190.

Bukhsh, Q. (2007). Empowerment of women through distance education in Pakistan. Online Submission, 8(4).

Cauchemez, S., Van Kerkhove, M. D., Archer, B. N., Cetron, M., Cowling, B. J., Grove, P., ... \& Oshitani, H. (2014). School closures during the 2009 Influenza pandemic: National and local experiences. BMC Infectious Diseases, 14(1), 207.

Covid-19 Stats. (2020). Retrieved from National Command Operation Center: https://ncoc.gov.pk/

Crawford, J., Butler-Henderson, K., Rudolph, J., \& Glowatz, M. (2020). COVID-19: 20 countries' higher education intra-period digital pedagogy responses. Journal of Applied Teaching and Learning (JALT), 3(1).

Cucinotta, D., \& Vanelli, M. (2020). WHO declares COVID-19 a pandemic. Acta Bio-Medica: Atenei Parmensis, 91(1), 157-160.

Farid, S., Ahmad, R., Niaz, I. A., Arif, M., Shamshirband, S., \& Khattak, M. D. (2015). Identification and prioritization of critical issues for the promotion of e-learning in Pakistan. Computers in Human Behavior, 51, 161-171.

Kaur, G. (2020). Digital Life: Boon or bane in teaching sector on COVID-19. CLIO an Annual Interdisciplinary Journal of History, 6(6), 416-427.

Kayani, U. R. (2005, December). FOSS Localization: A Solution for the ICT dilemma of developing countries. In 2005 Pakistan Section Multitopic Conference (pp. 1-5). IEEE. Anwar Journal of Pedagogical Sociology and Psychology, 2(1), 45-51

Liguori, E., \& Winkler, C. (2020). From offline to online: Challenges and opportunities for entrepreneurship education following the COVID-19 pandemic.

Mailizar, Almanthari, A., Maulina, S., \& Bruce, S. (2020). Secondary school mathematics teachers' views on e-learning implementation barriers during the Covid-19 pandemic: The case of Indonesia. Eurasia Journal of Mathematics, Science and Technology Education, 16(7), em1860.

McCarthy, K. (2020, March 7). The global impact of coronavirus on education. ABC News: https://abcnews.go.com/International/global-impact-coronaviruseducation/story

McPherson, M. S., \& Bacow, L. S. (2015). Online higher education: Beyond the hype cycle. The Journal of Economic Perspectives, 29(4), 135-153. 
Pace, C., Pettit, S. K., \& Barker, K. S. (2020). Best practices in middle level quaranteaching: Strategies, tips and resources amidst COVID-19. Becoming: Journal of the Georgia Association for Middle Level Education, 31(1), 2.

Salam, S., Jianqiu, Z., Pathan, Z. H., \& Lei, W. (2017). Strategic barriers in the effective integration of ICT in the public schools of Pakistan. Proceedings of the 2017 International Conference on Computer Science and Artificial Intelligence, 169-172. https:// doi.org/10.1145/3168390.3168422

Saqlain, M., Munir, M. M., Ahmed, A., Tahir, A. H., \& Kamran, S. (2020). Is Pakistan prepared to tackle the coronavirus epidemic? Drugs \& Therapy Perspectives, 1-2.

Toquero, C. M. (2020). Challenges and opportunities for higher education amid the COVID-19 pandemic: The Philippine context. Pedagogical Research, 5(4).

Wains, S. I., \& Mahmood, W. (2008). Integrating m-learning with e-learning. Proceedings of the 9th ACM SIGITE Conference on Information Technology Education, 31-38.

$\mathrm{Wu}, \mathrm{Z}$. (2020). How a top Chinese university is responding to coronavirus. World Economic Forum. https:// www.weforum.org/agenda/2020/03/coronavirus-china-the-challenges-ofonlinelearning-for-universities/

Yousuf, M. I. (2007). Effectiveness of mobile learning in distance education. Online Submission, $8(4), 114-124$.

Zhong, R. (2020, March 17). The coronavirus exposes education's digital divide. The New York Times. coronavirus.html

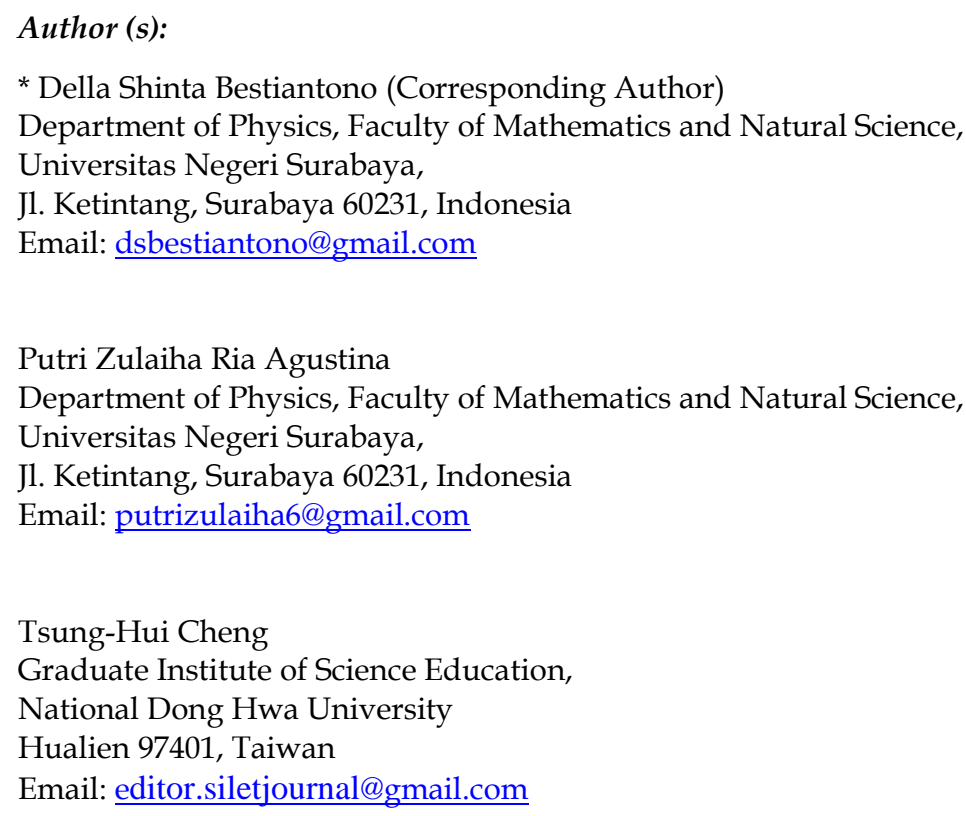

